\title{
Pengaruh Perlakuan Amalgamasi Terhadap Tingkat Perolehan Emas dan Kehilangan Merkuri
}

\section{Widodo $^{\mathrm{a}}$}

${ }^{a} U P T$ Loka Uji Teknik Penambangan Jampang Kulon-LIPI

\begin{abstract}
The gold ore as the result from selective mining "small scale mining" in Waluran, Sukabumi had been used as a raw material for the experimentation of amalgamation. The objective of this experiment is to obtain the trend of influence from factor of feed assay and the treatment of amalgamation to the recovery of gold metal and the looseness of mercury $(\mathrm{Hg})$. The experimentation was carried out by the factorial design from two factors. The treatment of amalgamation was carried out only to the process feed assay factor (low and high grade ore) and time factor of amalgamation process (direct and indirect process) relating to the input of mercury in amalgamator. These two factors were determined as independent variable. While the recovery of gold metal and the lossless of mercury were determined as dependent variable). The result of experimentation indicated that the treatment factor of amalgamation relating to the input of mercury in the amalgamator by indirect process is more dominant than the process feed assay factor. By this method both low grade and high grade of gold ore trend to increase the recovery of gold metal and to decrease of mercury. The amalgamation process with indirect process is better than the direct process, and it is indicated by the recovery of gold metal of $14,580 \%$, in addition to decrease of mercury of 3,933 \%. It is hoped that the experimentation result of this amalgamation can be used as a reference in designing of the experimentation of amalgamation as well as the application in the gold mining industry.
\end{abstract}

Key words : amalgamation, gold treatment (Au), the mercury looseness

ABSTRAK Sampel bijih emas hasil dari penambangan secara selektif "pertambangan rakyat" di Waluran, Sukabumi telah digunakan sebagai bahan percobaan amalgamasi. Tujuan percobaan untuk memperoleh pola kecenderungan (trend) pengaruh dari faktor kadar umpan dan perlakuan amalgamasi terhadap tingkat perolehan (recovery) logam emas dan kehilangan merkuri (Hg). Percobaan dilaksanakan berdasarkan disain faktorial 2 level dari 2 faktor. Perlakuan amalgamasi hanya ditekankan pada faktor kadar umpan proses (bijih emas berkadar rendah dan bijih emas berkadar tinggi) dan faktor waktu proses amalgamasi (cara langsung dan cara tidak langsung) sehubungan dengan waktu memasukkan merkuri ke dalam amalgamator. Kedua faktor tersebut ditetapkan sebagai variabel independent, sedangkan tingkat perolehan logam emas dan kehilangan merkuri selama proses amalgamasi ditetapkan sebagai variabel dependent. Hasil percobaan mengindikasikan bahwa faktor perlakuan amalgamasi sehubungan dengan waktu memasukkan merkuri ke dalam amalgamator cara tidak langsung lebih dominan berpengaruh dibandingkan faktor kadar umpan proses. Dengan cara tersebut, baik untuk bijih emas berkadar rendah maupun yang berkadar tinggi memberikan pola kecenderungan meningkatkan perolehan logam emas dan pola kecenderungan menekan tingkat kehilangan merkuri. Proses amalgamasi dengan cara tidak langsung lebih baik dibandingkan dengan cara langsung, dan mampu meningkatkan perolehan logam emas hingga 14,580 \% dan menekan tingkat kehilangan merkuri hingga 3,933 \%. Hasil percobaan amalgamasi ini, diharapkan dapat digunakan sebagai bahan acuan dalam perencanaan percobaan amalgamasi maupun penerapannya dalam industri pertambangan emas.

Kata kunci : amalgamasi, perolehan emas (Au), kehilangan merkuri (Hg) 


\section{PENDAHULUAN}

Penambangan bijih emas pada "pertambangan rakyat" di daerah Waluran, Sukabumi dilakukan dengan sistem tambang bawah tanah, dengan membuat lubang bukaan mendatar berupa terowongan (tunnel) atau berupa adit dan lubang bukaan vertikal berupa sumuran (shaft) sebagai jalan masuk ke dalam tambang. Penambangan dilakukan dengan menggunakan peralatan sederhana (seperti pahat, palu, cangkul, sekop dan belincong) dan dilakukan secara selektif untuk memilih bijih yang mengandung emas baik yang berkadar rendah maupun yang berkadar tinggi. Hasil penambangan tersebut diolah dengan metoda amalgamasi, yaitu proses pengikatan logam emas dari bijih tersebut dengan menggunakan merkuri ( $\mathrm{Hg}$ ) dalam tabung yang disebut sebagai gelundung (amalgamator). Amalgamator selain berfungsi sebagai tempat proses amalgamasi juga berperan dalam mereduksi ukuran butir bijih dari bijih yang berbutir kasar $(1 \mathrm{~cm})$ hingga berbutir halus (80 - 200 mesh) dengan media gerus berupa batangan besi bekas rel. Amalgamator tersebut diputar dengan tenaga penggerak air sungai melalui kincir atau tenaga listrik (dinamo). Hasil amalgamasi selanjutnya dilakukan pencucian dan pendulangan untuk memisahkan amalgam (perpaduan logam emas/perak dengan Hg) dari ampas (tailing). Amalgam yang diperoleh diproses melalui pembakaran (penggebosan) untuk memperoleh perpaduan logam emas-perak (bullion), selanjutnya dilakukan pemisahan antara logam emas ( $\mathrm{Au}$ ) dari logam perak (Ag) dengan menggunakan larutan perak nitrat.

Kenyataan di lapangan menunjukkan bahwa hasil proses amalgamasi pada "pertambangan rakyat" di Waluran, Sukabumi umumnya menimbulkan berbagai permasalahan disamping terjadinya pemborosan sumberdaya mineral juga menimbulkan terjadinya degradasi lingkungan. Terjadinya pemborosan sumberdaya karena banyak logam emas yang terbuang bersama dengan ampas (tailing) yang tercermin oleh tingkat perolehan (recovery) logam emas yang masih rendah ( $<50 \%)$, walaupun secara teoritis tingkat perolehan emas dalam amalgamasi jarang melebihi 85 \% (Sevruykov, et.al, 1960). Terjadinya degradasi lingkungan khususnya di daerah aliran sungai disebabkan oleh proses pencucian dan pendulangan yang dilakukan di sungai sehingga ampas (tailing) terbuang ke dalam sungai. Sebagai akibatnya sungai menjadi keruh dan tercemar oleh merkuri yang terbuang bersama ampas. Hasil pemantauan Dinas Pertambangan dan Energi Kabupaten Sukabumi menyebutkan bahwa di daerah aliran sungai di Kecamatan Waluran pada umumnya telah mengalami pencemaran merkuri (Hg) akibat kegiatan pertambangan emas di daerah sekitarnya. Kandungan merkuri telah berada diatas nilai ambang batas yang diperkenankan, hasil pengukuran terhadap kualitas air pada bulan Agustus 2005 memperlihatkan nilai kandungan merkuri (Hg) cukup tinggi, yaitu mencapai sekitar 0,2180 mg/l (Wahyu, dkk., 2006). Untuk mengetahui kondisi sebenarnya proses amalgamasi yang dilakukan pada “pertambangan rakyat” di Waluran, maka dilakukan percobaan amalgamasi dengan indikator tingkat perolehan logam emas dan tingkat kehilangan merkuri (Hg) .

Percobaan amalgamasi dilakukan dengan menggunakan bahan dan peralatan yang sama sebagaimana dilakukan oleh "pertambangan rakyat" di daerah Waluran. Permasalahannya adalah bagaimana pengaruh dari perlakuan amalgamasi terhadap tingkat perolehan (recovery) logam emas dan kehilangan merkuri (Hg). Sedangkan tujuan percobaan adalah untuk memperoleh pola kecenderungan (trend) pengaruh dari hasil perlakuan amalgamasi tersebut. Percobaan amalgamasi dilaksanakan berdasarkan disain faktorial 2 level dari 2 faktor. Hasil percobaan amalgamasi ini, diharapkan dapat digunakan sebagai bahan acuan dalam perencanaan percobaan amalgamasi maupun penerapannya dalam industri pertambangan emas. 


\section{METODOLOGI}

\section{Bahan dan peralatan:}

Bahan percobaan yang digunakan adalah 2 kelompok bijih emas berukuran $<1 \mathrm{~cm}$, masing-masing berkadar rendah (8,4 gr/ton) dan berkadar tinggi (10,32 gr/ton). Bahan proses amalgamasi berupa merkuri (Hg), kapur tohor untuk pengaturan $\mathrm{pH}$. Sedangkan bahan proses selanjutnya berupa borax, soda abu dan perak nitrat. Sedangkan peralatan amalgamasi berupa gelundung (amalgamator) dengan tenaga penggerak kincir air, pendulang dan retorting.

\section{Metoda percobaan}

Disain faktorial 2 level dari 2 faktor (Tabel 1), terdiri dari perlakuan amalgamasi berupa faktor kadar umpan proses (8,4 gr/ton dan 10,32 gr/ton) dan faktor waktu proses amalgamasi (9 jam dan 2 jam) sehubungan dengan perlakuan waktu memasukkan merkuri (Hg) ke dalam amalgamator ditetapkan sebagai variabel independen (penyebab). Sedangkan tingkat perolehan logam emas dan kehilangan merkuri (Hg) selama proses amalgamasi ditetapkan sebagai variabel dependen atau akibat (Box, 1978).

\section{Prosedur percobaan}

Prosedur percobaan amalgamasi dilakukan dengan 2 cara, yaitu cara langsung dan cara tidak langsung dijelaskan sebagai berikut :

\section{Prosedur cara langsung $\left(X_{1}\right)$ :}

Kondisi percobaan diatur sebagai berikut : berat bijih emas $20 \mathrm{~kg}$, berat media giling 9,6 kg, berat air raksa 150 gr, pH pulp 9 - 10, kecepatan putar tabung amalgamasi pada penghalusan bijih adalah $55 \mathrm{rpm}$, dan rentang waktu amalgamasi 9 jam (dimana merkuri dimasukkan bersama-sama proses penggerusan).

Tabel 1. Disain faktorial 2 level dari 2 faktor

\begin{tabular}{|c|c|c|c|}
\hline \multirow{2}{*}{\multicolumn{2}{|c|}{$\begin{array}{l}\text { DISAIN } \\
\text { FAKTORIAL }\end{array}$}} & \multicolumn{2}{|c|}{ Faktor waktu amalgamasi (jam)* } \\
\hline & & \multirow{2}{*}{$\begin{array}{c}\mathrm{X}_{1} \\
\begin{array}{c}\text { Cara langsung } \\
(9 \text { jam })\end{array} \\
X_{1} Y_{1}\end{array}$} & \multirow{2}{*}{$\begin{array}{c}\mathrm{X}_{2} \\
\begin{array}{c}\text { Cara tidak langsung } \\
(2 \mathrm{jam})\end{array} \\
\mathrm{X}_{2} \mathrm{Y}_{1}\end{array}$} \\
\hline \multirow{2}{*}{$\begin{array}{l}\text { Faktor } \\
\text { kadar } \\
\text { umpan } \\
\text { (gr/ton) }\end{array}$} & $\begin{array}{c}Y_{1} \\
(8,4 \text { gr/ton })\end{array}$ & & \\
\hline & $\begin{array}{c}\mathbf{Y}_{2} \\
(10,32 \text { gr/ton })\end{array}$ & $\mathbf{X}_{1} \mathbf{Y}_{2}$ & $\mathbf{X}_{2} \mathbf{Y}_{2}$ \\
\hline
\end{tabular}

*) sehubungan dengan perlakuan waktu memasukkan merkuri (Hg) ke dalam amalgamator

\section{Prosedur cara tidak langsung $\left(X_{2}\right)$ :}

Kondisi percobaan sama dengan kondisi cara langsung $\left(\mathrm{X}_{1}\right)$, perbedaannya bahwa bijih emas tidak langsung dimasukan ke amalgamator, tetapi dilakukan pencucian terlebih dahulu. Selanjutnya dilakukan penghalusan ukuran butir dalam amalgamator selama 7 jam, kemudian baru tahap amalgamasi selama 2 jam. Pada tahap amalgamasi ini, dilakukan pengurangan berat media giling 40-50 \%, ditambahkan air untuk mendapatkan persen pulp (adonan) menjadi 30 - 40 \%, dimasukan air raksa dan pengecekan $\mathrm{pH}$ (9-10). Setelah persiapan 
pengolahan selesai, tabung amalgamasi diputar kembali dengan kecepatan putar sekitar 40 rpm. Pengurangan berat media giling dan kecepatan putar bertujuan agar proses yang terjadi hanya proses pengadukan (agitasi) bukan proses penggerusan.

Hasil amalgamasi berupa amalgam, selanjutnya dengan menambahkan borax, soda abu, nitrat kemudian dibakar dengan alat emposan (retort), didapatkan bullion. Pemisahan logam emas terhadap perak dilakukan dengan menggunakan larutan air keras (asam nitrat) dan batang tembaga sebagai elektroda, perak akan bereaksi dengan air keras, dan emas akan tertinggal.

\section{HASIL DAN DISKUSI}

Pengolahan bijih emas dengan metoda amalgamasi merupakan cara pengolahan bijih emas yang paling sederhana dibandingkan dengan metoda pengolahan lainnya, seperti metoda flotasi maupun metoda pelindian termasuk sianidasi. Disamping murah biaya operasionalnya, juga mudah dalam pemasaran produknya karena baik masih dalam bentuk amalgam, bullion maupun berupa logam emas sudah bisa dipasarkan dengan harga standar berdasarkan kualitas produk dan harga pasar logam emas murni dunia internasional pada saat itu. Oleh karena itu, metoda amalgamasi ini menjadi pilihan utama bagi pertambangan skala kecil (pertambangan rakyat) pada umumnya.

Hasil percobaan amalgamasi baik dalam bentuk amalgam, bullion maupun logam emas (Au) dan kehilangan merkuri (Hg) disajikan dalam bentuk tabel seperti disajikan pada Tabel 2. Nampak bahwa perlakuan waktu amalgamasi sehubungan dengan cara memasukkan merkuri (Hg) ke dalam amalgamator yang dilakukan secara tidak langsung (2 jam) memperoleh hasil amalgamasi lebih baik jika dibandingkan dengan cara langsung (9 jam) sebagaimana yang dilakukan oleh "pertambangan rakyat" di Waluran pada umumnya. Walaupun waktu amalgamasi cara langsung relatif lebih lama dibandingkan dengan cara tidak langsung (selisih waktu 7 jam), tetapi sesungguhnya yang paling dominan berpengaruh adalah parameter-parameter perlakuan amalgamasinya.

Tabel 2. Hasil percobaan amalgamasi

\begin{tabular}{|c|c|c|c|c|c|}
\hline \multirow{2}{*}{ No. } & \multirow{2}{*}{$\begin{array}{c}\text { Variabel } \\
\text { percobaan }\end{array}$} & \multicolumn{3}{|c|}{ Hasil percobaan amalgamasi (gr) } & \multirow{2}{*}{$\begin{array}{l}\text { Kehilangan } \\
\text { merkuri (gr) }\end{array}$} \\
\hline & & Amalgam & Bullion & Emas (Au) & \\
\hline 1 & $\mathrm{X}_{1} \mathrm{Y}_{1}$ & $\begin{array}{l}8,100 \\
7,590\end{array}$ & $\begin{array}{l}1,666 \\
1,610\end{array}$ & $\begin{array}{l}0,0810 \\
0,0690\end{array}$ & $\begin{array}{c}10,60 \\
9,20\end{array}$ \\
\hline 2 & $\mathrm{X}_{1} \mathrm{Y}_{2}$ & $\begin{array}{l}9,610 \\
9,080\end{array}$ & $\begin{array}{l}1,480 \\
1,724\end{array}$ & $\begin{array}{l}0,0785 \\
0,0798\end{array}$ & $\begin{array}{l}11,50 \\
12,10\end{array}$ \\
\hline 3 & $\mathrm{X}_{2} \mathrm{Y}_{1}$ & $\begin{array}{l}9,620 \\
9,740\end{array}$ & $\begin{array}{l}1,760 \\
2,075\end{array}$ & $\begin{array}{l}0,0868 \\
0,0756\end{array}$ & $\begin{array}{l}7,10 \\
6,80\end{array}$ \\
\hline 4 & $\mathrm{X}_{2} \mathrm{Y}_{2}$ & $\begin{array}{l}11,650 \\
11,480\end{array}$ & $\begin{array}{l}2,532 \\
1,886\end{array}$ & $\begin{array}{l}0,0986 \\
0,1096\end{array}$ & $\begin{array}{l}7,90 \\
6,20\end{array}$ \\
\hline
\end{tabular}

\section{Tingkat perolehan (recovery) :}

Hasil percobaan baik dalam bentuk amalgam, bullion maupun logam emas masing-masing dihitung tingkat perolehan (recovery) dengan persamaan sebagai berikut (Sanwani dan Sudarsono, 1995) :

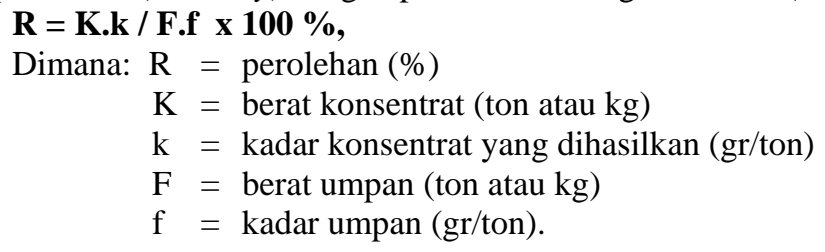


Hasil perhitungan tingkat perolehan berdasarkan data pada Tabel 2, disajikan dalam bentuk diagram seperti terlihat pada Gambar 1.

\section{Tingkat kehilangan merkuri (Hg) :}

Sedangkan tingkat kehilangan merkuri dihitung berdasarkan persamaan berikut :

$$
\begin{aligned}
\mathbf{K}=\mathbf{B} / \mathbf{A} \mathbf{x} \mathbf{1 0 0} \%, \\
\text { Dimana : } \mathrm{K}=\text { kehilangan merkuri (\%) } \\
\mathrm{A}=\text { berat awal merkuri yang digunakan, (gr) } \\
\mathrm{B}=\text { berat merkuri yang hilang dalam proses, (gr). }
\end{aligned}
$$

Berdasarkan data mengenai besarnya kehilangan merkuri (Hg) pada Tabel 2, tingkat kehilangan merkuri (Hg) disajikan dalam bentuk diagram pada Gambar 2.

Berdasarkan diagram gambar 1, nampak bahwa pola kecenderungan (trend) pengaruh perlakuan amalgamsi cara tidak langsung mempunyai kecenderungan dapat meningkatkan perolehan logam emas ( $\mathrm{Au}$ ) rata-rata sebesar 14,580 \%, jika dibandingkan dengan cara tidak langsung. Sementara berdasarkan diagram gambar 2, nampak bahwa pola kecenderungan (trend) pengaruh perlakuan amalgamsi cara tidak langsung mempunyai kecenderungan dapat menurunkan (menekan) tingkat kehilangan merkuri (Hg) rata-rata sebesar 3,933 \%, jika dibandingkan dengan cara tidak langsung.

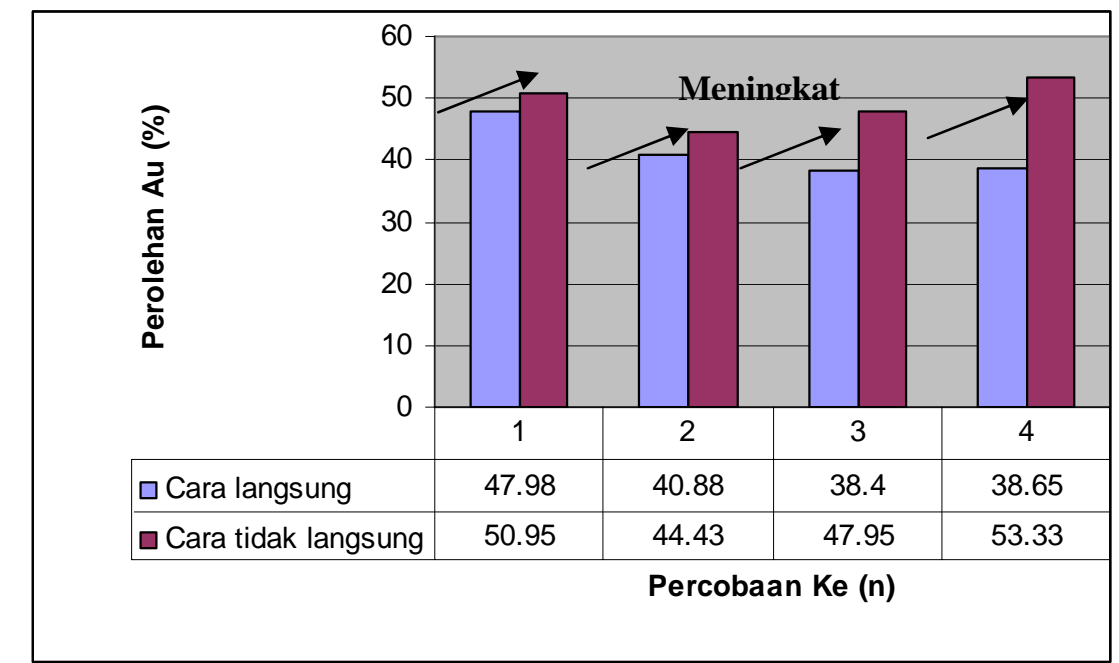

Gambar 1. Diagram pola kecenderungan tingkat perolehan logam emas hasil percobaan amalgamasi

Mengingat terbatasnya sarana dan waktu penelitian, sehingga ukuran sample atau minimnya jumlah percobaan, maka hasil penelitian ini belum bisa menunjukkan data yang valid, karena tidak bisa dianalisis secara statistik. Perlakuan seperti pencucian umpan, pengurangan media giling, pengurangan pulp density, pengurangan kecepatan putar (rpm) maupun pengaturan $\mathrm{pH}$ inilah sesungguhnya yang paling dominan mempengaruhi tingkat perolehan emas dan tingkat kehilangan merkuri (Hg). Oleh karena itu, parameter-parameter tersebut yang sebaiknya diteliti lebih mendalam untuk penelitian berikutnya. 


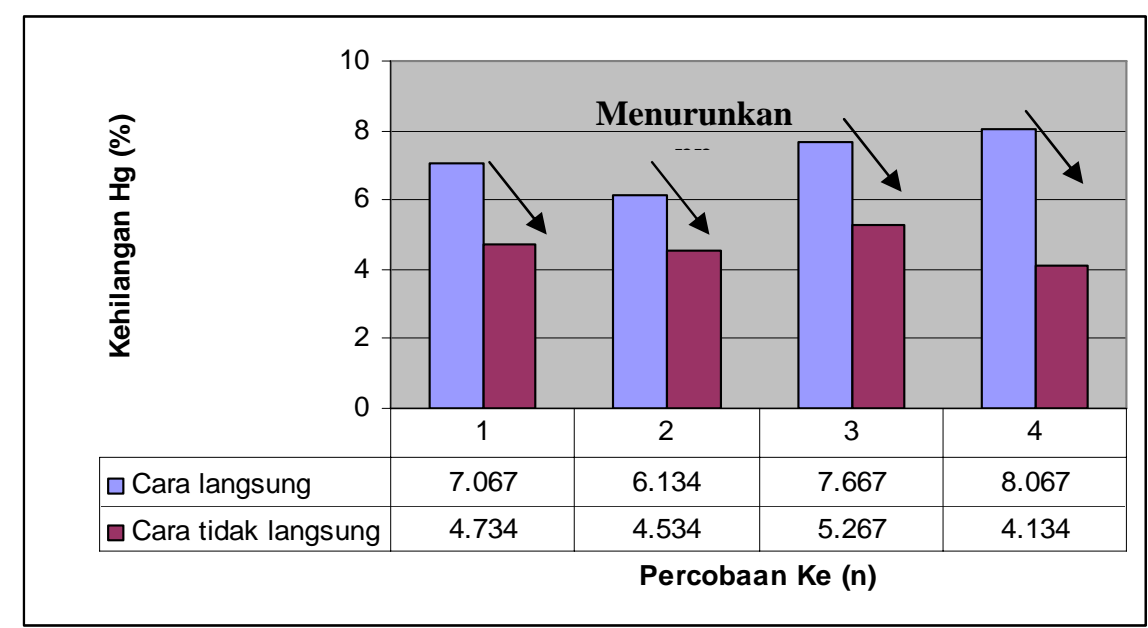

Gambar 2. Diagram pola kecenderungan tingkat kehilangan merkuri (Hg) hasil percobaan amalgamasi

\section{KESIMPULAN}

Proses amalgamasi dengan cara tidak langsung sehubungan dengan waktu memasukkan merkuri (Hg) ke dalam amalgamator dapat diperoleh baik hasil amalgam, bullion maupun logam emas serta kehilangan merkuri lebih baik dibandingkan dengan cara amalgamasi tidak langsung.

Proses amalgamasi dengan cara tidak langsung akibat perlakuan amalgamasi memberikan pola kecenderungan (trend) dapat meningkatkan perolehan logam emas $\mathrm{(Au}$ ) dan pola kecenderungan (trend) dapat menekan tingkat kehilangan merkuri (Hg).

Proses amalgamasi dengan cara tidak langsung dibandingkan dengan cara langsung lebih dapat meningkatkan perolehan logam emas hingga 14,580 \% dan menekan tingkat kehilangan merkuri (Hg) hingga 3,933\%.

\section{UCAPAN TERIMAKASIH}

Ucapan terima kasih kami sampaikan kepada Kepala Dinas Pertambangan dan Energi Kabupaten Sukabumi beserta staf, atas kesempatan dan kepercayaan yang diberikan kepada penulis dalam sosialisasi hasil pemantauan pencemaran air raksa dari pengolahan emas di Kecamatan Waluran, Kabupaten Sukabumi. Ir. Toto Wahyu, Ir. Bambang Sudarsono, Ir. Zaki Yadin dan Ir. Muchlis, dll.nya atas kerjasamanya yang baik selama sosialisasi hasil pemantauan pencemaran air raksa dari pengolahan emas di Kecamatan Waluran, Kabupaten Sukabumi dilaksanakan. Sdr. H. Daen, S. pengolah bijih emas yang telah membantu pembakaran amalgam dan pemurnian untuk mendapatkan logam emas. Dr. Ir. Eko Yulianto, Ir. Eko Tri Sumarnadi dan Redaksi Riset Geologi Pertambangan atas koreksi dan masukannya, sehingga tulisan ini dapat terbit. 


\section{DAFTAR PUSTAKA}

Gaudin, A.M., 1939. Principles of Mineral Dressing, Mc. Graw-Hill Book Company, New York.

Sevruykov, N.; Kuzmin, B.; dan Chelishchev, Y., 1960. General Matallurgy, Peace Publisher, Moscow.

Sanwani, E., dan Sudarsono, A., 1995. Perolehan, Nisbah Konsentrasi dan Kadar Pada Pengolahan Bahan Galian, Warta PERHAPI, September-Oktober, Jakarta.

Pelle, R., 1956. “Mining Engineers” Hand Book, Third Edition, Vol. 2, John Willey and Sons Inc., New York.

Taggart, A.F, 1960. Handbook Of Mineral Dressing, Ores and Industrial Minerals, John Willey and Sons Inc., New York

Wahyu, T., Sudarsono, B., dan Zakiyadin, 2006, Sosialisasi Hasil Pemantauan Pencemaran Air Raksa Dari Pengolahan Emas Di Waluran Tahun 2006, Dinas Pertambangan dan Energi, Kabupaten Sukabumi, 23 Agustus 2006.

Naskah masuk: 20 Mei 2008 Naskah diterima: 10 Juli 2008 